\title{
Screening of potential inhibitors for COVID-19 main protease from phytoconstituents of Tectona grandis Linn: application of molecular modeling studies
}

\section{Anoop K}

School of Lifesciencess, Kannur University https://orcid.org/0000-0002-9613-3259

\section{Varun T K}

School of Lifesciencess, Kannur University

Ajeesh A K

School of Lifesciencess, Kannur University

\section{Aravind A}

School of Lifesciencess, Kannur University

\section{Muhammad Azharuddin M}

School of Lifesciencess, Kannur University

\section{Praveen $\mathbf{P}$}

School of Lifesciencess, Kannur University

\section{Sayeed Ali M P}

School of Lifesciencess, Kannur University

Jayadevi Variyar E ( $\nabla$ ejayadevi@gmail.com )

School of Lifesciencess, Kannur University

\section{Research Article}

Keywords: Novel Coronavirus, COVID-19, Protease, Molecular Docking, Tectona grandis Linn

Posted Date: April 7th, 2020

DOI: https://doi.org/10.21203/rs.3.rs-21617/v1

License: (c) (1) This work is licensed under a Creative Commons Attribution 4.0 International License. Read Full License 


\section{Abstract}

The recent outbreak of novel coronavirus disease, COVID-19 has created a threat to human population across the world. The unavailability of specific therapeutics and vaccines, demands the sincere efforts in this direction. Main Proteases of this novel Coronavirus (SARS-CoV-2) play critical role during the disease propagation, and hence represents a crucial target for the drug discovery. Reported phytoconstituents of T. grandis Linn were prepared for docking evaluation. The current objective of the study is to identify some naturally occurring product from Tectona grandis Linn. and evaluate its binding activity against COVID-19 Major protease as novel Coronavirus (SARS-CoV-2) target through in silico docking studies. The study results showed that all the selected phytoconstituents showed binding energy ranging between -7.723 to $-1.524 \mathrm{kcal} / \mathrm{mol}$. Barleriaquinone-l exhibited highest binding affinity $-7.723 \mathrm{Kcal} / \mathrm{mol}$ and strong, stable interactions with the amino acid residues present on the active site of COVID-19 Main Protease. Our findings suggest that these phytoconstituents molecules can be used as potential inhibitors against COVID-19 Main Protease. However, further investigation and validation of these inhibitors against SARSCoV-2 are needed to claim their candidacy for clinical trials

\section{Introduction}

Medicinal plants have been widely used to treat a wide variety of infectious as well as non-infectious ailments. Many of the plant derived compounds exhibit antiviral properties and are found to be effective against various viral infections. Due to their low toxicity and possible multi- step mechanism, which means, lesser selective pressure for the emergence of resistant strains, natural products have been encouraged for searching new drugs. In addition, the majority of the compounds used for the clinical purpose are targeted for a diminutive number of viruses. (De Clercq, 2004) Ethnopharmacological screenings of the medicinal plants have shown that a vast number of phytochemicals such as alkaloids, anthraquinones, coumarins, flavonoids, polyphenols, tannins, terpenoids, among others, are active against virus. (Hupfeld and Efferth, 2009)The antiviral activity of the natural compounds may occur by inhibition of one or more steps of viral replication. By direct interaction with the viral particle, they can prevent infection; change of the adsorption venture by official to cell receptors; hindrance of infection infiltration into the host cell, by viewing for pathways of actuation of intracellular signs, and all the more regularly, meddling with various phases of viral replication (Ghosh et al., 2009). Coronaviruses (CoVs) are the family of viruses containing single-stranded RNA (positive-sense) which is encapsulated by a membrane envelope. They are classified in the Nidovirales order, Coronaviridae family, which is comprised of two sub-families and about 40 known species. These species are divided and characterized into four gene era (alpha, beta, gamma and delta), and only the alpha and beta- strains are identified to be pathogenic to human and other mammals (Y. Chen et al., 2020; Paules et al., 2020) Before 2019, six coronaviruses were known to cause respiratory and enteric diseases in humans, especially the two of them belonging to betaviruses cause severe illness: SARS (Severe Acute Respiratory Syndrome)-CoV and MERS (Middle East Respiratory Syndrome)-CoV. (Hui et al., 2020; Song et al., 2019). On 7 January 2020, a new coronavirus, 2019-nCoV (now officially named SARS-CoV-2) was implicated in an alarming outbreak 
of a pneumonia-like illness COVID-19, originating from Wuhan City, Hubei, China. Human-to-human transmission was first confirmed in Guangdong, China (Y. W. Chen et al., 2020). The World Health Organization has declared global public health emergency on 4 March 2020 as there are more than 90,000 confirmed cases reported, and the death toll is over 3000 . In the height of the crisis, this virus is spreading at a rate and scale far worse than previous coronaviral epidemics. Coronaviruses possess extraordinarily large single- stranded RNA genomes-approximately 26 to 32 kilo bases in length. This genome acts just like a messenger RNA when it infects a cell, and directs the synthesis of two long polyproteins that include the machinery that the virus needs to replicate new viruses. These proteins include a replication/transcription complex that makes more RNA, several structural proteins that construct new virions, and two proteases. The proteases play essential roles in cutting the polyproteins into all of these functional pieces. It is a dimer of two identical subunits that together form two active sites. The protein fold is similar to serine proteases like trypsin, but a cysteine amino acid and a nearby histidine perform the protein-cutting reaction and an extra domain stabilizes the dimer. This structure has a peptide-like inhibitor bound in the active site (Cui et al., 2019; St John et al., 2015). Bioinformatics is one of the most important and innovative approaches in the design and manufacture of new drugs. Since the clinical and laboratory trials are costly and tedious in nature, various bioinformatics techniques are nowadays used for designing new drugs. Molecular docking, simulation, target point determination and chemical stability studies are the most important bioinformatics methods used in drug design. In the meantime, molecular docking has a special place in the process of designing new drugs, examining and comparing their efficacy (Grinter and Zou, 2014; Mukesh and Rakesh, 2011).

Tectona grandis Linn (Teak), is locally known as Sagwan, belongs to Lamiaceae family. It is one of the most valuable timber in the world, due to its beautiful surface and its resistance to termite and fungal damage. The main active ingredient compounds that are responsible for these action are tectoquinone, lapachol and deoxylapachol. Naphthoquinones, anthraquinones and isoprenoid quinones are abundant metabolites in teak. In addition to these, teak contains several other phytochemicals such as triterpenoids, steroids, lignans, fatty esters and phenolic compounds. Pharmacologically, the plant has been investigated for antioxidant, anti-inflammatory, anti- pyretic, cytotoxic, analgesic, hypoglycemic, wound healing and antiplasmodial activities. Based on the above view, the aim of our study is to identify some naturally occurring product and evaluate its binding activity against against COVID-19 major protease through in silico molecular docking studies.

\section{Methods}

Glide docking uses the hypothesis of a rigid receptor although scaling of van der Waals radii of nonpolar atoms, which decreases penalties for close contacts, can be used to model a slight "give" in the receptor and/or ligand. Docking studies of designed compounds were carried out using grid-based ligand docking with energetics (GLIDE) module version 5.9. Schrödinger, LLC, New York, NY, 2013. The software package running on multiprocessor Linux PC. GLIDE has previously been validated and applied successfully to predict the binding orientation of many ligands. 


\section{Data sources}

In this study, a dataset of active phytochemicals were obtained from FDA and Indian Medicinal Plants, Phytochemistry, and Therapeutics and pubchem database.

\section{Protein structure preparation}

The X-ray crystal structures of COVID-19 major protease (PDB: 6LU7) (Prajapat et al., 2020) retrieved from the RCSB Protein Data Bank (https://www.rcsb.org/structure/6LU7) PDB is an archive for the crystal structures of biological macromolecules, worldwide (Jayaprakasha et al., 2002). Water molecules of crystallization were removed from the complex, and the protein was optimized for docking using the protein grounding and refinement utility provided by Schrödinger LLC.

\section{Determination of Active Sites}

The amino acids in the active site of a protein were determined using the Computed Atlas for Surface Topography of Proteins (CASTp) (http://sts.bioe.uic.edu/castp/index.html?201I) and Biovia Discovery Studio 4.5. The determination of the amino acids in the active site was used to analyze the Grid box and docking evaluation results. Discovery Studio is an offline life sciences software that provides tools for protein, ligand, and pharmacophore modelling (Gopal Samy and Xavier, 2015).

\section{Target protein and ligand preparation}

The structures of energetic constituents of T. Grandis were constructed by means of the splinter dictionary of Maestro 9.3 (Schrodinger, LLC) using the optimized potentials for liquid simulations-all atom force field with the steepest descent followed by curtailed Newton conjugate gradient protocol. The crystal structure of the above-mentioned targets was downloaded from the Protein Data Bank (PDB) and Pubchem databases. The selected protein targets were prepared for docking studies using the protein preparation wizard module in Schrodinger program (Maestro 9.3.). The preparation includes force field parameters assignment, energy minimization and $\mathrm{H}$-bond assignment. The energy minimized models of ligands obtained after molecular modeling studies were then prepared using ligprep module. Geometries of ligands was optimized using OPLS-2005 force field and ionization generates possible states at target $\mathrm{pH} 7.0 \pm 2.0$

Receptor Grid preparation and Molecular Docking

All docking calculations were performed using the "extra precision" mode of GLIDE program. A receptor grid that defines the specific area of the protein to which the interaction of ligand has to be tested was defined by the receptor grid generation module. The position of the co- crystal ligand defines the Centre of the grid For the binding site, an assortment of energy grids was premeditated and stored, is distinct in terms of two concentric cubes: The bounding box, which must contain the center of any satisfactory ligand pose, and the enclosing box, which must contain all ligand atoms of an satisfactory pose, with a root mean square deviation of $<0.5 \AA$ and a maximum atomic displacement of $<1.3 \AA$ were eliminated as unneeded to increase assortment in the retained ligand poses. The scale factor for van der Waals radii was applied to those atoms with absolute partial charges $\leq 0.15$ (scale factor of 0.8 ) and 0.25 (scale factor of 1.0) electrons for ligand and protein, respectively. Energy minimization protocol includes 
dielectric constant of 4.0 and 1000 steps of conjugate gradient. Upon end of each docking calculation, for the most part, 100 poses per ligand were generated. The most excellent docked structure be preferred using a GLIDE score (G-score) function (Amudha and Rani, 2016; Parasuraman et al., 2014)

Glide Score $=0.065 * v d W+0.130 *$ Coul + Lipo + Hbond + Metal + BuryP + RotB + Site

Analysis and visualization

Visual analysis of the docking site was performed using Pymol version 2.3.4 and the results were validated using Schrodinger program (Maestro 9.3.)

ADME analysis

On the basis of canonical SMILES of the selected ligands obtained from pubchem, ADME properties of the studied compound were calculated using online Swiss ADME program. The major parameters for ADME associated properties such as Lipinski's rule of five, the solubility of the drug, pharmacokinetic properties and drug likeliness were considered. The values of the observe properties are presented in Table 3.

\section{Results And Discussion}

Coronaviruses (CoVs) are the family of viruses containing single-stranded RNA (positivesense) which is encapsulated by a membrane envelope. They are classified in the Nidovirales order, Coronaviridae family, which is comprised of two sub-families and about 40 known species. These species are divided and characterized into four gene era (alpha, beta, gamma and delta), and only the alpha and beta- strains are identified to be pathogenic to human and other mammals. Bioinformatics is one of the most important and innovative approaches in the design and manufacture of new drugs. Due to the high cost of clinical and laboratory trials, the time consuming and the possibility of error, various bioinformatics techniques are nowadays used in the design of new drugs. Molecular docking, simulation, target point determination and chemical stability studies are the most important bioinformatics methods used in drug design. In the meantime, molecular docking of a special place in the process of designing new drugs, examining and comparing their efficacy enjoyable (Grinter and Zou, 2014; Mukesh and Rakesh, 2011). One of the novel therapeutic strategies for virus infection apart from the design and chemical synthesis of protease inhibitors is the search for inhibitors of this enzyme among natural compounds in order to obtain drugs with minimal side effects. T. grandis has variety of medicinal properties and traditional uses. Virtually every part of the teak tree has medicinal properties. The decoction of bark is used in bronchitis, hyperacidity, dysentery, verminosis, burning sensation, diabetes, difficult labor, leprosy and skin diseases (Vyas et al., 2019). It is important to know that, which secondary plant metabolites are found in plant as it may provide a basis for its traditional uses. During more than 100 years of intensive research on the chemistry of $T$. grandis, various compounds have been detected from different parts of the plant includes Quinones are major secondary metabolites and other common phytochemicals (Table 1). The figure 1-7 shows the structures of the compounds that identified from the plant and selected for the in silico studies. 
Table 1: Compounds isolated from T. grandis.

\begin{tabular}{|l|l|}
\hline Compound name (Molecular formula) & \multicolumn{1}{|c|}{ Plant part \& References } \\
\hline NAPHTHOQUINONES & $\begin{array}{l}\text { Heartwood (GUPTA and SINGH, 2004; } \\
\text { Martin et al., 1974) }\end{array}$ \\
\hline 1.Lapachol(C15H14O3) & $\begin{array}{l}\text { Heartwood (Burnett and Thomson, } \\
\text { 1967; Gupta } \\
\text { and Singh, 2004) }\end{array}$ \\
\hline 2.Deoxylapachol (C15H14O2) & Root heartwood (Khan and Mlungwana, 1999) \\
\hline $\begin{array}{l}\text { 3. 5-Hydroxylapachol (C15H14O4) } \\
\text { 4. 4. Hydroxysesamone (C15H14O5) }\end{array}$ & Leaves (Kopa et al., 2014) \\
\hline 5. $\alpha$-Lapachone (C15H14O3) & Roots (Krishna et al., 1977) \\
\hline 6. $\beta$-Lapachone (C15H14O3) & Heartwood (Gupta and Singh, 2004) \\
\hline 7. Dehydro- $\alpha$-lapachone (C15H12O3) & Heartwood (Mounguengui et al., 2016) \\
\hline $\begin{array}{l}\text { 8. 4'5'-Dihydroxy-epiisocatalponol } \\
\text { (C15H18O4) }\end{array}$ & Heartwood (Lukmandaru and Takahashi, 2009) \\
\hline 9. Tectol (C30H26O4) & Heartwood (Gupta and Singh 2004) \\
\hline 10. Dehydro- $\alpha$-isodunnione (C15H12O3) & Heartwood (Gupta and Singh, 2004) \\
\hline 11. Tecomaquinone-I (C30H24O4) & $\begin{array}{l}\text { Heartwood (Sandermann and Simatupang, } \\
1966)\end{array}$ \\
\hline ANTHRAQUINONES & \\
\hline 12. Tectoquinone (C15H10O2) &
\end{tabular}




\begin{tabular}{|c|c|}
\hline $\begin{array}{l}\text { 13. 2-Hydroxymethyl- } \\
\text { anthraquinone } \\
\text { (C15H1003) }\end{array}$ & (Windeisen et al., 2003) \\
\hline $\begin{array}{l}\text { 14.2-Acetoxymethyl- } \\
\text { anthraquinone } \\
\text { (C15H12O4) }\end{array}$ & Heartwood (Rudman, 1960) \\
\hline $\begin{array}{l}\text { 15. Anthraquinone-2- } \\
\text { carbaldehyde (C15H8O3) }\end{array}$ & Heartwood (Rudman, 1960) \\
\hline $\begin{array}{l}\text { 16. Anthraquinone-2-carboxylic } \\
\text { acid } \\
\text { (C15H8O4) }\end{array}$ & Heartwood (Rudman, 1960) \\
\hline $\begin{array}{l}\text { 17. 3-Hydroxy-2-methyl- } \\
\text { anthraquinone } \\
\text { (C15H1003) }\end{array}$ & Heartwood (Kopa et al., 2014) \\
\hline 18. Pachybasin (C15H10O3) & Heartwood (Thomson, 2012) \\
\hline 19. Rubiadin (C15H10O4) & Heartwood (Burnett and Thomson, 1968) \\
\hline 20. Munjistin (C15H8O6) & $\begin{array}{l}\text { Heartwood (Burnett and Thomson 1968) Roots } \\
\text { (Joshi et al.1977) }\end{array}$ \\
\hline $\begin{array}{l}\text { 21. 2-Methylquinizarin } \\
\text { (Ci5H10O4) }\end{array}$ & $\begin{array}{l}\text { Heartwood (Sandermann and Simatupang 1966) Root } \\
\text { (Khan and Mlungwana 1999) }\end{array}$ \\
\hline 22. Quinizarine (C14H8O4) & Leaves (Kopa et al. 2014) \\
\hline $\begin{array}{l}\text { 23. 1-Hydroxy-2-methyl } \\
\text { anthraquinone } \\
\text { (C15H1003) }\end{array}$ & Stem (Windeisen et al. 2003) \\
\hline $\begin{array}{l}\text { 24.5,8-dihydroxy-2- } \\
\text { methylanthraquinone } \\
\text { (C15H1004) }\end{array}$ & Leaves (Kopa et al. 2014) \\
\hline 25. Obtusifolin (C16H12O5) & Saw dust (Sumthong et al., 2008) \\
\hline $\begin{array}{l}\text { 26. 9,10-Dimethoxy-2-methyl-1,4- } \\
\text { anthraquinone(C17H14O4) }\end{array}$ & Heartwood (Singh et al., 1989) \\
\hline $\begin{array}{l}\text { 27.5-Hydroxy-2-methyl } \\
\text { anthraquinone } \\
\text { (C15H1003) }\end{array}$ & Heartwood (Agarwal et al., 1965) \\
\hline $\begin{array}{l}\text { 28. 1-Hydroxy-5-methoxy-2- } \\
\text { methylanthraquinone(C16H12O4) }\end{array}$ & Heartwood (Agarwal et al., 1965) \\
\hline $\begin{array}{l}\text { 29.1,5-Dihydroxy- } \\
\text { 2methylanthraquinone } \\
\text { (C15H1004) }\end{array}$ & Heartwood (Agarwal et al., 1965) \\
\hline $\begin{array}{l}\text { 30. 5-Hydroxydigitolutein } \\
\text { (C16H12O5) }\end{array}$ & Tissue culture (Dhruva et al., 1972) \\
\hline $\begin{array}{l}\text { 31. Barleriaquinone-I } \\
\text { (C15H1003) }\end{array}$ & Heartwood (Singh et al. 2008) \\
\hline $\begin{array}{l}32 . \\
\text { Tectoleafquinone (C19H14O6) }\end{array}$ & Leaves (Agarwal et al., 1965) \\
\hline $\begin{array}{l}\text { 33. Grandiquinone A } \\
\text { (C17H12O5) }\end{array}$ & Leaves (Kopa et al. 2014) \\
\hline 34. Tectograndone (C30H20O10) & Leaves (Kopa et al. 2014) \\
\hline 35. Anthratectone (C27H18O9) & Leaves (Lacret et al., 2011) \\
\hline 36. Naphthotectone (C17H16O7) & Leaves (Lacret et al., 2011) \\
\hline \multicolumn{2}{|l|}{ MONOTERPENE } \\
\hline $\begin{array}{l}\text { 37. (6RS)-(E)-2,6-Dimethyl-2,7- } \\
\text { octadiene-1,6- } \\
\text { diol (C10H18O2) }\end{array}$ & Leaves (Macias et al. 2008) \\
\hline
\end{tabular}


Page $8 / 28$ 


\begin{tabular}{|c|c|}
\hline SESQUITERPENES & \\
\hline $\begin{array}{l}\text { 38. 1 } \beta-6-\alpha-\text {-Dihydroxy- } \\
4(15) \text {-eudesmene } \\
\text { (C15 } \\
\text { H26O2) }\end{array}$ & Leaves and Bark (Macias et al.2010) \\
\hline $\begin{array}{l}\text { 39. 7-Epieudesm- } \\
\text { 4(15)-ene-1 } \alpha, 6 \alpha \text {-diol } \\
\text { (C15 } \\
\text { H26O2) }\end{array}$ & Leaves and Bark (Macias et al. 2010) \\
\hline \multicolumn{2}{|l|}{ DITERPENES } \\
\hline $\begin{array}{l}\text { 40. Abeograndinoic } \\
\text { Acid (C2OH32O4) }\end{array}$ & Leaves and Bark (Macias et al. 2010) \\
\hline 41. Phytol (C20H40O) & Leaves and Bark (Macias et al. 2010) \\
\hline $\begin{array}{l}\text { 42. 7,11,15-Trimethyl- } \\
\text { hexethylene- } \\
\text { hexadecan- } \\
\text { 1,2-diol (C20H40O2) }\end{array}$ & Leaves and Bark (Macias et al. 2010) \\
\hline $\begin{array}{l}\text { 43. Rhinocerotinoic } \\
\text { acid (C20H30O3) }\end{array}$ & Leaves and Bark (Macias et al. 2010) \\
\hline $\begin{array}{l}\text { 44.2-Oxokovalenic } \\
\text { acid (C20H30O3) }\end{array}$ & Leaves and Bark (Macias et al. 2010) \\
\hline $\begin{array}{l}\text { 45. } 19- \\
\text { Hydroxyferruginol } \\
\text { (C20H30O2) }\end{array}$ & Leaves and Bark (Macias et al. 2010) \\
\hline $\begin{array}{l}\text { 46. Tectograndinol } \\
\text { (C20H34O3) }\end{array}$ & Leaves (Horst and Ilona 1977) \\
\hline $\begin{array}{l}\text { 47. Solidagonal acid } \\
\text { (C20H30O3) }\end{array}$ & Leaves and Bark (Macias et al. 2010) \\
\hline \multicolumn{2}{|l|}{ TRITERPENES } \\
\hline 48. Lupeol (C30H50O) & Bark (Pathak et al. 1988) \\
\hline $\begin{array}{l}\text { 49. Betulin } \\
\text { (C30H50O2) }\end{array}$ & Bark (Pathak et al. 1988) \\
\hline $\begin{array}{l}\text { 50. Betulinaldehyde } \\
\text { (C30H48O2) }\end{array}$ & Bark (Pathak et al.1988) \\
\hline $\begin{array}{l}\text { 51. Betulinic acid } \\
\text { (C30H48O3) }\end{array}$ & $\begin{array}{l}\text { Heartwood and Stem bark (Sandermann and Simatupang 1966; } \\
\text { Khan al. } \quad \text { et } \\
\text { (Ahluwalia and Seshadri 1957) Roots (Dayal and } \\
\text { Seshadri 1979) Leaves (Kopa et al. 2014) }\end{array}$ \\
\hline $\begin{array}{l}\text { 52. Ursolic acid } \\
\text { (C30H48O3) }\end{array}$ & $\begin{array}{l}\text { Leaves (Kopa et al. 2014); Bark (Macias et al. } \\
\text { 2010) }\end{array}$ \\
\hline $\begin{array}{l}\text { 53. Corosolic acid } \\
\text { (C30H48O4) }\end{array}$ & Leaves (Kopa et al. 2014) \\
\hline $\begin{array}{l}\text { 54. Oleanolic acid } \\
\text { (C30H48O3) }\end{array}$ & Leaves and Bark (Macias et al. 2010) \\
\hline $\begin{array}{l}\text { 55. Maslinic acid } \\
\text { (C30H48O4) }\end{array}$ & Leaves and Bark (Macias et al. 2010) \\
\hline $\begin{array}{l}\text { 56. Methyl-2 } \alpha, 3 \alpha- \\
\text { dihydroxyurs-12-en-28- } \\
\text { oate } \\
\text { (C30H48O4) }\end{array}$ & Leaves and Bark (Macias et al. 2010) \\
\hline $\begin{array}{l}\text { 57. Euscaphic acid } \\
\text { (C30H48O5) }\end{array}$ & Leaves and Bark (Macias et al. 2010) \\
\hline $\begin{array}{l}\text { 58. Squalene } \\
\text { (C30H50) }\end{array}$ & Roots (Windeisen et al. 2003; Khan and Mlungwana 1999 \\
\hline \multicolumn{2}{|c|}{ POLYTERPENE OR RUBBER } \\
\hline
\end{tabular}




\begin{tabular}{|l|l|}
$\begin{array}{l}\text { 59. Caoutchouc or } \\
\text { Indian rubber Polymer }\end{array}$ & $\begin{array}{l}\text { Wood (Sandermann and Dietrichs 1959; } \\
\text { Narayanamurti and Singh 1960; Yamamoto et al. }\end{array}$ \\
\hline APOCAROTENOIDS \\
\hline $\begin{array}{l}\text { 60. Tectoionol A } \\
\text { (Ci3H23O3) }\end{array}$ & Leaves (Macías et al., 2008) \\
\hline $\begin{array}{l}\text { 61. Tectoionol B } \\
\text { (C13H24O2) }\end{array}$ & Leaves (Macias et al. 2008) \\
\hline
\end{tabular}




\begin{tabular}{|c|c|}
\hline 62. Annuionone D (C13H20O3) & Leaves (Macias et al. 2008) \\
\hline $\begin{array}{l}\text { 63. 33-Hydroxy-7,8-dihydro- } \beta \text {-ionol } \\
\text { (C13H24O2) }\end{array}$ & Leaves (Macias et al. 2008) \\
\hline $\begin{array}{l}\text { 64. 9(S)-4-Oxo-7,8-dihydro- } \beta \text {-ionol } \\
\text { (C13H22O2) }\end{array}$ & Leaves (Macias et al. 2008) \\
\hline $\begin{array}{l}\text { 65. 33-Hydroxy-7,8-dihydro- } \beta \text {-ionone } \\
\text { (C13H22O2) }\end{array}$ & Leaves (Macias et al. 2008) \\
\hline \multicolumn{2}{|l|}{ PHENOLIC COMPOUNDS } \\
\hline 66. Gallic acid (C7H6O5) & Leaves (Nayeem and Karvekar, 2010) \\
\hline 67. Ellagic acid (C14H6O8) & Leaves (Nayeem and Karvekar 2010) \\
\hline 68. Acetovanillone (C9H10O3) & Leaves (Lacret et al. 2012) \\
\hline 69. E-Isofuraldehyde (C10H10O3) & Leaves (Lacret et al. 2012) \\
\hline $\begin{array}{l}\text { 70. 3-Hydroxy-1-(4-hydroxy-3,5- } \\
\text { dimethoxyphenyl) } \\
\text { propan-1-one (C1 1H14O5) }\end{array}$ & Leaves (Lacret et al. 2012) \\
\hline 71. Evofolin A (C17H1806) & Leaves (Lacret et al. 2012) \\
\hline \multicolumn{2}{|l|}{ FLAVONOIDS } \\
\hline 72. Rutin (C27H30O16) & Leaves (Nayeem and Karvekar 2010) \\
\hline 73. Quercitin (C15H10O7) & Leaves (Nayeem and Karvekar 2010) \\
\hline \multicolumn{2}{|l|}{ STEROIDS/ SAPONINS } \\
\hline 74. $\beta$-Sitosterol (C29H50O) & $\begin{array}{l}\text { Roots (Joshi et al. 1977; Dayal } \\
\text { and Seshadri } \\
\text { 1979) }\end{array}$ \\
\hline 75. Hydroxyenone (C29H48O2) & Leaves and Bark (Macias et al. 2010) \\
\hline $\begin{array}{l}\text { 76. } \beta \text {-Sitosterol- } \beta \text {-d-[4'linolenyl-6'-(tridecan- } \\
\text { 4"-one-1"-oxy)] Glucuranopyranoside } \\
\text { (C66H11008) }\end{array}$ & Stem bark (Khan et al., 2010) \\
\hline $\begin{array}{l}\text { 77. Stigmast-5-en-3-O- } \beta-d-g l u c o p y r a n o s i d e \\
\text { (C35H6006) }\end{array}$ & $\begin{array}{l}\text { Stem bark (Khan et al., 2010; Misra et } \\
\text { al., 2008) }\end{array}$ \\
\hline $\begin{array}{l}\text { 78. Sitosterol 3-O- } \beta \text {-d-glucopyranoside } \\
\text { (C60H10007) }\end{array}$ & $\begin{array}{l}\text { Leaves (Kopa et al. 2014; Singh et al. } \\
2010\end{array}$ \\
\hline 79. Syringaresinol (C22H26O8) & $\begin{array}{l}\text { Leaves (Lacret et al. 2012; Macias et al. } \\
\text { 2008) }\end{array}$ \\
\hline 80. Medioresinol (C21H24O7) & $\begin{array}{l}\text { Leaves (Lacret et al. 2012; Macias et al. } \\
\text { 2008) }\end{array}$ \\
\hline 81. 1-Hydroxypinoresinol (C20H22O7) & Leaves (Lacret et al. 2012) \\
\hline 82. Lariciresinol (C20H24O6) & $\begin{array}{l}\text { Leaves (Lacret et al. 2012; Macias et al. } \\
\text { 2008) }\end{array}$ \\
\hline 83. Balaphonin (C20H20O6) & Leaves (Lacret et al. 2012) \\
\hline 84. Zhebeiresinol (C14H16O6) & Leaves (Lacret et al. 2012) \\
\hline \multicolumn{2}{|l|}{ PHENYLPROPANOIDS : NORLIGNAN } \\
\hline 85. Tectonoelin A (C18H16O6) & Leaves (Lacret et al. 2012) \\
\hline
\end{tabular}




\begin{tabular}{|l|l|}
\hline 86. Tectonoelin B (C19H1807) & Leaves (Lacret et al. 2012) \\
\hline PHENYLETHANOID GLYCOSIDE & \\
\hline 87. Verbascoside or acteoside (C29H36015) & Leaves (Singh et al. 2010) \\
\hline FATTY ESTERS & Stem bark (Khan et al. 2010) \\
\hline $\begin{array}{l}\text { 88. 7'-Hydroxy-n-octacosanoyl n- } \\
\text { decanoate(C28H56O3 }\end{array}$ & Stem bark (Khan et al. 2010) \\
\hline $\begin{array}{l}\text { 89. 20'-Hydroxyeicosanyl linolenate } \\
\text { (C38H72O3) }\end{array}$ & Stem bark (Khan et al. 2010) \\
\hline $\begin{array}{l}\text { 90. 18'-Hydroxy-n-hexacosanyl-n-decanoate } \\
\text { (C36H72O3) }\end{array}$ & \\
\hline MISCELLANEOUS & (Khan et al. 2010) \\
\hline 91. n-Docosane (C22H46) Stem bark & Wood (Lacret et al. 2012) \\
\hline 92. O-Tolylmethylether (C8H10O)
\end{tabular}

The docking investigation was completed for the ligands with the target protein Mpro (COVID-19 major protease) (PDB: 6LU7) by means of the docking software GLIDE, and the docked images of compound showing high docking score are given in Figs. 9.1 - 9.10. The Mpro in coronavirus is very important for the proteolytic maturation of the virus. Mpro has been examined as a potential target to prevent the spread of infection by inhibiting viral polyprotein cleavage through blocking active sites of the protein. (Figure 8). The active site in the protein 6 LU7 consists of two chains; (i) small molecule- 02J (5-methylisoxasole-3carboxylic acid) with PR0168 amino acid residue present in the active site. (ii) PJE-C-5-: composite ligand with THR26, VAL3, GLY143, SER144, HIS163, HIS164, GLU166 amino acid residues present in the active side. With this new discovery of Mpro structure in COVID-19, it has provided an immense opportunity to identify potential drug candidates for the treatment of coronavirus.

In molecular docking, the binding energy suggests the affinity of a specific ligand and strength by which a compound interacts with and binds to the pocket of a target protein. A compound with a lower binding energy is preferred as a possible drug candidate. In order to understand the effect of active antiviral and phytochemicals compounds on COVID-19. The structures docked by GLIDE are usually ranked according to the GLIDE scoring function (more negative). The scoring function of GLIDE docking program is offered in the G-score form. The most clear-cut method of evaluating the precision of a docking procedure is to determine how intimately the lowest energy pose (binding conformation) predicted by the object scoring function. To study the molecular basis of interaction and likeness of binding of ligands to COVID-19 Mpro, all the ligands were docked into the active site of COVID-19 Mpro. The docking result of these ligands is prearranged in Table 2.

Table 2: Glide score for the docked ligands 


\begin{tabular}{|c|c|c|c|c|}
\hline S. No. & Compound & Pubchem CID & Glide RMSD & Glide score \\
\hline 1 & Barleriaquinone-I & 155237 & 70.397 & -7.723 \\
\hline 2 & Tectoquinone & 6773 & 68.495 & -6.895 \\
\hline 3 & Deoxylapachol & 97448 & 69.848 & -6.643 \\
\hline 4 & Quercitin & 5280343 & 72.325 & -6.507 \\
\hline 5 & Evofolin B & 5317306 & 72.456 & -6.446 \\
\hline 6 & Quinizarine & 6688 & 73.316 & -6.133 \\
\hline 7 & Munjistin & 160476 & 70.822 & -5.986 \\
\hline 8 & Grandiquinone A & 102236728 & 73.347 & -5.896 \\
\hline 9 & Lapachol & 3884 & 69.426 & -5.683 \\
\hline 10 & 4-Methylquinoline & 10285 & 69.386 & -5.642 \\
\hline 11 & Rubiadin & 124062 & 70.419 & -5.559 \\
\hline 12 & Tecomaquinone-I & 3574508 & 73.598 & -5.521 \\
\hline 13 & Acetovanillone & 2214 & 70.835 & -5.404 \\
\hline 14 & Ellagic acid & 5281855 & 72.292 & -5.347 \\
\hline 15 & Annuionone a & 72828705 & 69.007 & -4.936 \\
\hline 16 & Tectol & 161453 & 70.231 & -4.325 \\
\hline 17 & Betulinaldehyde & 99615 & 74.955 & -4.271 \\
\hline 18 & Syringaresinol & 100067 & 69.146 & -4.205 \\
\hline 19 & Solidagonal acid & 101285195 & 68.635 & -4.198 \\
\hline 20 & Verbascoside & 5281800 & 67.322 & -4.12 \\
\hline 21 & Medioresinol & 181681 & 70.315 & -4.118 \\
\hline 22 & Phytol & 5280435 & 69.141 & -4.074 \\
\hline 23 & Lariciresinol & 332427 & 66.907 & -4.033 \\
\hline 24 & Rhinocerotinoic acid & 11771531 & 71.253 & -3.998 \\
\hline 25 & Lupeol & 259846 & 73.759 & -3.675 \\
\hline 26 & Betulinic acid & 64971 & 73.34 & -3.648 \\
\hline 27 & Rutin & 5280805 & 67.847 & -1.524 \\
\hline
\end{tabular}

The interaction energy includes van der Waals energy, electrostatic energy, as well as intermolecular hydrogen bonding were calculated for each minimized complex. The docking score by means of GLIDE varied from -7.723 to -1.524 against COVID-19 major protease. 
From the docking studies it is clear that all the compounds that are interacted at the active site of the COVID-19 Mpro (figure 10). All the compounds are thermodynamically feasible and shows significant glide score and they bind the hydrophobic pocket of the active site. The molecular docking analysis in the present study showed the inhibitory potential of 10 selected compounds, ranked by affinity $(\Delta G)$; Barleriaquinone-I > Tectoquinone $>$ Deoxylapachol $>$ Quercitin $>$ Evofolin $B>$ Quinizarine $>$ Munjistin $>$ Grandiquinone A > Lapachol > 4- Methylquinoline.

Lipinski's rule of five is a major criterion to evaluate drug likeliness and if a particular chemical compound with a certain biological and pharmacological activity has physical and chemical properties that would make it a likely orally active drug in humans. Lipinski's rule determines the molecular properties which are important for a drug's pharmacokinetics in the human body such as absorption, distribution, metabolism, and excretion (ADME). Lipinski's rule of five criteria for an ideal drug are (i) a molecular mass less than 500 Daltons, (ii) no more than 5 hydrogen bond donors, (iii) no more than 10 hydrogen bond acceptors, (iv) an octanol-water partition coefficient $\log P$ not greater than 5 . Three or more than 3 violations do not fit into the criteria of drug likeliness and it is not considered in order to proceed with drug discovery. ADME studies of selected 27 compounds showed that out of 20 virtual hits were successful at passing through these ADME test filters (Table 3). This preliminary screening of potential molecules would help in providing the fast in-silico analysis towards development of therapeutics for COVID-19.

Due to technical limitations, Table 3 is provided in the Supplementary Files section.

The other targets for the selected compounds was done using SwissTargetPrediction method and it is based on the observation that similar bioactive molecules are more likely to share similar targets. Here the compounds showed high glide score for COVID-19 Mpro and also obeys the Lipinskis rule of five was selected for the prediction of other targets. From the analysis of Barleriaquinone-l it has an $30 \%$ probability with proteases enzyme target class among them most predicted target was Leukocyte elastase (figure 11) the other predicted targets with probability was given in the table 4. Table 5,6 and figure 11,12 shows the predicted targets for Tectoquinone and Deoxylapachol respectively. Tectoquinone targets phosphatases class and the most predicted target was dual specificity phosphatase Cdc25B were as Deoxylapachol targets Oxidoreductase class and predicted target was Monoamine oxidase B.

Table 4: Top 7 predicted targets and class for Barleriaquinone-I 


\begin{tabular}{|l|l|l|l|l|c|}
\hline \multicolumn{1}{|c|}{ Target } & $\begin{array}{c}\text { Common } \\
\text { name }\end{array}$ & $\begin{array}{l}\text { Uniprot } \\
\text { ID }\end{array}$ & \multicolumn{1}{|c|}{$\begin{array}{c}\text { Target } \\
\text { Class }\end{array}$} & Probability & $\begin{array}{c}\text { Known } \\
\text { actives } \\
(3 \mathrm{DD} / 2 \mathrm{D})\end{array}$ \\
\hline Leukocyte elastase & ELANE & P08246 & Protease & 0.271400463 & $35 / 20$ \\
\hline Estrogen receptor beta & ESR2 & Q92731 & $\begin{array}{l}\text { Nuclear } \\
\text { receptor }\end{array}$ & 0.171518552 & $17 / 12$ \\
\hline Estrogen receptor alpha & ESR1 & P03372 & $\begin{array}{l}\text { Nuclear } \\
\text { receptor }\end{array}$ & 0.117056358 & $10 / 12$ \\
\hline $\begin{array}{l}\text { Serine/threonine- } \\
\text { protein kinase PIM1 }\end{array}$ & PIM1 & P11309 & Kinase & 0.098947479 & $32 / 2$ \\
\hline Casein kinase II alpha & CSNK2A1 & P68400 & Kinase & 0.080792387 & $5 / 3$ \\
\hline $\begin{array}{l}\text { Protein-tyrosine } \\
\text { phosphatase 4A3 }\end{array}$ & PTP4A3 & O75365 & Phosphatase & 0.071715932 & $1 / 1$ \\
\hline $\begin{array}{l}\text { Protein } \\
\text { farnesyltransferase }\end{array}$ & FNTA FNTB & $\begin{array}{l}\text { P49354 } \\
\text { P49356 }\end{array}$ & Enzyme & 0.071715932 & $10 / 2$ \\
\hline
\end{tabular}

Table 5: Top 7 predicted targets and class for Tectoquinone

\begin{tabular}{|l|l|l|l|l|l|}
\hline \multicolumn{1}{|c|}{ Target } & $\begin{array}{c}\text { Common } \\
\text { name }\end{array}$ & $\begin{array}{l}\text { Uniprot } \\
\text { ID }\end{array}$ & $\begin{array}{l}\text { Target } \\
\text { Class }\end{array}$ & Probability & $\begin{array}{l}\text { Known } \\
\text { actives } \\
\text { (3D/2D) }\end{array}$ \\
\hline $\begin{array}{l}\text { Dual specificity } \\
\text { phosphatase } \\
\text { Cdc25B }\end{array}$ & CDC25B & P30305 & Phosphatase & 0.075973634 & $11 / 5$ \\
\hline Leukocyte elastase & ELANE & P08246 & Protease & 0.048952898 & $37 / 14$ \\
\hline $\begin{array}{l}\text { Acyl coenzyme A: } \\
\text { cholesterol } \\
\text { acyltransferase 1 }\end{array}$ & SOAT1 & P35610 & Enzyme & 0.048952898 & $5 / 0$ \\
\hline P2X purinoceptor 7 & P2RX7 & Q99572 & $\begin{array}{l}\text { Ligand- } \\
\text { gated } \\
\text { ion channel }\end{array}$ & 0.048952898 & $196 / 0$ \\
\hline Dopamine D4 receptor & DRD4 & P21917 & $\begin{array}{l}\text { Family A } \\
\text { G protein- } \\
\text { coupled } \\
\text { receptor }\end{array}$ & 0.048952898 & $24 / 0$ \\
\hline Myeloperoxidase & MPO & P05164 & Enzyme & 0.048952898 & $14 / 0$ \\
\hline Gamma-secretase & PSEN2 & P49810 & Protease & 0.048952898 & $39 / 0$ \\
\hline
\end{tabular}

Table 6: Top 7 predicted targets and class for Deoxylapachol 


\begin{tabular}{|l|l|l|l|l|c|}
\hline \multicolumn{1}{|c|}{ Target } & $\begin{array}{l}\text { Common } \\
\text { name }\end{array}$ & $\begin{array}{l}\text { Uniprot } \\
\text { ID }\end{array}$ & Target Class & Probability & $\begin{array}{l}\text { Known } \\
\text { actives } \\
(3 \mathrm{D} / 2 \mathrm{D})\end{array}$ \\
\hline Monoamine oxidase B & MAOB & P27338 & Oxidoreductase & 0.075973634 & $367 / 3$ \\
\hline $\begin{array}{l}\text { Indoleamine } \\
\text { 2,3- } \\
\text { dioxygenase }\end{array}$ & IDO1 & P14902 & Enzyme & 0.075973634 & $30 / 12$ \\
\hline $\begin{array}{l}\text { G-protein coupled } \\
\text { receptor 35 }\end{array}$ & GPR35 & Q9HC97 & $\begin{array}{l}\text { Family A G } \\
\text { protein- } \\
\text { coupled } \\
\text { receptor }\end{array}$ & 0.057956876 & $0 / 1$ \\
\hline $\begin{array}{l}\text { Dual specificity } \\
\text { phosphatase Cdc25B }\end{array}$ & CDC25B & P30305 & Phosphatase & 0.057956876 & $20 / 13$ \\
\hline P2X purinoceptor 7 & P2RX7 & Q99572 & $\begin{array}{l}\text { Ligand- } \\
\text { gated ion } \\
\text { channel }\end{array}$ & 0.048952898 & $274 / 0$ \\
\hline Monoamine oxidase A & MAOA & P21397 & Oxidoreductase & 0.048952898 & $158 / 2$ \\
\hline Glutathione reductase & GSR & P00390 & Oxidoreductase & 0.048952898 & $4 / 4$ \\
\hline
\end{tabular}

\section{Conclusion}

The rate of COVID-19 infection in China is declining and new shocking outbreaks are emerging in Italy, Indonesia, South Korea, India, middle east and Europe, with a major risk for a pandemic situation. The scientific community is hence called for a collaborative and extraordinary effort for a rapid identification of an effective anti-COVID-19 drug. In this matter, we hope that our contribution through drug repurposing against target COVID-19 major protease of novel coronavirus (COVID-19) can be of great help in such a worldwide endeavor. In conclusion, we have a notorious molecules Barleriaquinone-l, Tectoquinone, Deoxylapachol, and Quercitin, an inventive drug candidate that was docked against COVID-19 major protease in a premeditated attempt to ascertain a new drug candidate, which is able to obstruct the diverse key target points of COVID-19 in treating novel corona virus. This compound Barleriaquinone-I, Tectoquinone, Deoxylapachol, and Quercitin well calculated as a best (lead) molecule and we necessitate design analogs, synthesis and evaluate its effectiveness against viral disease caused by COVID-19 through the molecular level and in vivo studies.

\section{References}

1. Agarwal, S.C., Sarngadharan, M.G., Seshadri, T.R., 1965. Colouring matter of teak leaves: isolation and constitution of tectoleafquinone. Tetrahedron Lett. 6, 2623-2626.

https://doi.org/10.1016/S0040-4039(00)90218-1

2. Amudha, M., Rani, S., 2016. In silico molecular docking studies on the phytoconstituents of cadaba fruticosa (I.) Druce for its fertility activity. Asian J. Pharm. Clin. Res. 48-50.

3. Burnett, A.R., Thomson, R.H., 1968. Naturally occurring quinones. Part XV. Biogenesis of the anthraquinones in Rubia tinctorum L. (madder). J. Chem. Soc. C Org. 2437-2441. 
https://doi.org/10.1039/J39680002437

4. Burnett, A.R., Thomson, R.H., 1967. Naturally occurring quinones. Part X. The quinonoid constituents of Tabebuia avellanedae(Bignoniaceae). J. Chem. Soc. C Org. 2100-2104. https://doi.org/10.1039/J39670002100

5. Chen, Y., Liu, Q., Guo, D., 2020. Emerging coronaviruses: Genome structure, replication, and pathogenesis. J. Med. Virol. 92, 418-423. https://doi.org/10.1002/jmv.25681

6. Chen, Y.W., Yiu, C.-P.B., Wong, K.-Y., 2020. Prediction of the SARS-CoV-2 (2019-nCoV) 3C- like protease (3CLpro) structure: virtual screening reveals velpatasvir, ledipasvir, and other drug repurposing F1000Research 9, 129. https://doi.org/10.12688/f1000research.22457.1

7. Cui, J., Li, F., Shi, Z.-L., 2019. Origin and evolution of pathogenic coronaviruses. Nat. Rev. 17, 181192. https://doi.org/10.1038/s41579-018-0118-9

8. De Clercq, E., 2004. Antiviral drugs in current clinical use. J. Clin. Virol. Off. Publ. Pan Am. Soc. Virol. 30, 115-133. https://doi.org/10.1016/j.jcv.2004.02.009

9. Dhruva, b., br, d., av, r.r., r, s., k, v., 1972. Structure of a quinone from teak tissue culture. Struct. Quinone teak tissue Cult.

10. Ghosh, T., Chattopadhyay, K., Marschall, M., Karmakar, P., Mandal, P., Ray, B., 2009. Focus on antivirally active sulfated polysaccharides: from structure-activity analysis to clinical evaluation. Glycobiology 19, 2-15. https://doi.org/10.1093/glycob/cwn092

11. Gopal Samy, B., Xavier, L., 2015. Molecular Docking Studies on Antiviral Drugs for SARS. Int. Adv. Res. Comput. Sci. Softw. Eng. 5, 75-79.

12. Grinter, S.Z., Zou, X., 2014. Challenges, applications, and recent advances of protein-ligand docking in structure-based drug design. Mol. Basel Switz. 19, 10150-10176. https://doi.org/10.3390/molecules190710150

13. Gupta, p.k., singh, p., 2004. Note: a naphthoquinone derivative from tectona grandis (linn.). J. Asian Nat. Prod. Res. 6, 237-240. https://doi.org/10.1080/10286020310001653192

14. Gupta, K., Singh, P., 2004. A naphthoquinone derivative from Tectona grandis (Linn.). J. Asian Nat. Prod. Res. 6, 237-240. https://doi.org/10.1080/10286020310001653192

15. Hui, D.S., I Azhar, E., Madani, T.A., Ntoumi, F., Kock, R., Dar, O., Ippolito, G., Mchugh, T.D., Memish, Z.A., Drosten, C., Zumla, A., Petersen, E., 2020. The continuing 2019-nCoV epidemic threat of novel coronaviruses to global health - The latest 2019 novel coronavirus outbreak in Wuhan, Int. J. Infect. Dis. IJID Off. Publ. Int. Soc. Infect. Dis. 91, 264- 266. https://doi.org/10.1016/j.ijid.2020.01.009

16. Hupfeld, J., Efferth, T., 2009. Review. Drug resistance of human immunodeficiency virus and overcoming it by natural products. Vivo Athens Greece 23, 1-6.

17. Jayaprakasha, K., Jagan Mohan Rao, L., Sakariah, K.K., 2002. Improved HPLC Method for the Determination of Curcumin, Demethoxycurcumin, and Bisdemethoxycurcumin. J. Agric. Food Chem. 50, 3668-3672. https://doi.org/10.1021/jf025506a 
18. Khan, R.M., Mlungwana, S.M. (Department of A.S., 1999. 5-Hydroxylapachol: a cytotoxic agent from Tectona grandis. Phytochem. U. K.

19. Khan, Z., Ali, M., Bagri, P., 2010. A new steroidal glycoside and fatty acid esters from the stem bark of Tectona grandis Linn. Nat. Prod. Res. 24, 1059-1068. https://doi.org/10.1080/14786410902951088

20. Kopa, T.K., Tchinda, A.T., Tala, M.F., Zofou, D., Jumbam, R., Wabo, H.K., Titanji, V.P.K., Frédérich, M., Tan, N.-H., Tane, P., 2014. Antiplasmodial anthraquinones and hemisynthetic derivatives from the leaves of Tectona grandis (Verbenaceae). Phytochem. Lett. 8, 41-45.

https://doi.org/10.1016/j.phytol.2014.01.010

21. Krishna, C.J., Singh, P., Pardasani, R.T., 1977. Chemical components of the roots of Tectona grandis and Gmelina arborea. Planta Med. 32, 71-75. https://doi.org/10.1055/s-0028- 1097561

22. Lacret, , Varela, R.M., Molinillo, J.M.G., Nogueiras, C., Macías, F.A., 2011. Anthratectone and naphthotectone, two quinones from bioactive extracts of Tectona grandis. J. Chem. Ecol. 37, 13411348. https://doi.org/10.1007/s10886-011-0048-8

23. Lukmandaru, G., Takahashi, K., 2009. Radial distribution of quinones in plantation teak (Tectona grandis L.f.). Ann. For. Sci. 66, 605-605. https://doi.org/10.1051/forest/2009051

24. Macías, F.A., Lacret, R., Varela, R.M., Nogueiras, C., Molinillo, J.M.G., 2008. Bioactive apocarotenoids from Tectona grandis. Phytochemistry 69, 2708-2715.

https://doi.org/10.1016/j.phytochem.2008.08.018

25. Martin, F.W., Service, U.S.F., Sidki), L.D. (Sadik, 1974. National Forest landscape management.

1. Agricultural Research Service, U.S. Department of Agriculture.

26. Misra, L., Mishra, P., Pandey, A., Sangwan, R.S., Sangwan, N.S., Tuli, R., 2008. Withanolides from Withania somnifera roots. Phytochemistry 69, 1000-1004.

https://doi.org/10.1016/j.phytochem.2007.10.024

27. Mounguengui, S., Saha Tchinda, J.-B., Ndikontar, M.K., Dumarçay, S., Attéké, C., Perrin, D., Gelhaye, E., Gérardin, P., 2016. Total phenolic and lignin contents, phytochemical screening, antioxidant and fungal inhibition properties of the heartwood extractives of ten Congo Basin tree Ann. For. Sci. 73, 287-296. https://doi.org/10.1007/s13595-015-0514-5

28. Mukesh, B., Rakesh, K.Y., 2011. Molecular docking: a review [WWW Document]. URL https://www.semanticscholar.org/paper/molecular-docking\%3a-a-review-MukeshRakesh/65bacc6bf0191e2c4295748dbf091af371840284 (accessed 4.6.20).

29. Nayeem, N., Karvekar, 2010. Isolation of phenolic compounds from the methanolic extract of Tectona grandis. Res. J. Pharm. Biol. Chem. Sci. 1, 221-225.

30. Parasuraman, P., Swaminathan, S., Dhanaraj, P., 2014. Balancing anti-amyloid and anticholinesterase capacity in a single chemical entity: InSilico drug design. Int. J. Pharm. Pharm. Sci. 2, 571-574.

31. Paules, C.I., Marston, H.D., Fauci, A.S., 2020. Coronavirus Infections-More Than Just the Common Cold. JAMA 323, 707-708. https://doi.org/10.1001/jama.2020.0757 
32. Prajapat, M., Sarma, P., Shekhar, N., Avti, P., Sinha, S., Kaur, H., Kumar, S., Bhattacharyya, A., Kumar, , Bansal, S., Medhi, B., 2020. Drug targets for corona virus: A systematic review. Indian J. Pharmacol. 52, 56-65. https://doi.org/10.4103/ijp.IJP_115_20

33. Rudman, P., 1960. Anthraquinones of Teak (Tectona grandis L.F.). Chem. Ind. 44, 1356-7.

34. Sandermann, W., Simatupang, M.H., 1966. Zur Chemie und Biochemie des Teakholzes (Tectona grandis L. fil). Holz Als Roh- Werkst. 24, 190-204. https://doi.org/10.1007/BF02610269

35. Singh, P., Jain, S., Bhargava, S., 1989. A 1,4-Anthraquinone derivative from Tectona grandis.Phytochemistry 28, 1258-1259. https://doi.org/10.1016/0031-9422(89)80224-9

36. Song, Z., Xu, Y., Bao, L., Zhang, L., Yu, P., Qu, Y., Zhu, H., Zhao, W., Han, Y., Qin, C., 2019. From SARS to MERS, Thrusting Coronaviruses into the Spotlight. Viruses 11. https://doi.org/10.3390/v11010059

37. St John, S.E., Tomar, S., Stauffer, S.R., Mesecar, A.D., 2015. Targeting zoonotic viruses: Structurebased inhibition of the $3 \mathrm{C}$-like protease from bat coronavirus HKU4-The likely reservoir host to the human coronavirus that causes Middle East Respiratory Syndrome (MERS). Bioorg. Med. Chem. 23, 6036-6048. https://doi.org/10.1016/j.bmc.2015.06.039

38. Sumthong, P., Romero-González, R.R., Verpoorte, R., 2008. Identification of Anti-Wood Rot Compounds in Teak (Tectona grandis L.f.) Sawdust Extract. J. Wood Chem. Technol. 28, 247-260. https://doi.org/10.1080/02773810802452592

39. Thomson, R., 2012. Naturally Occurring Quinones. Elsevier.

40. Vyas, P., Yadav, D.K., Khandelwal, P., 2019. Tectona grandis (teak) - A review on its phytochemical and therapeutic potential. Nat. Prod. Res. 33, 2338-2354. https://doi.org/10.1080/14786419.2018.1440217

41. Windeisen, E., Klassen, A., Wegener, G., 2003. On the chemical characterisation of plantation teakwood from Panama. Holz Als Roh- Werkst. 61, 416-418. https://doi.org/10.1007/s00107-0030425-2

\section{Figures}



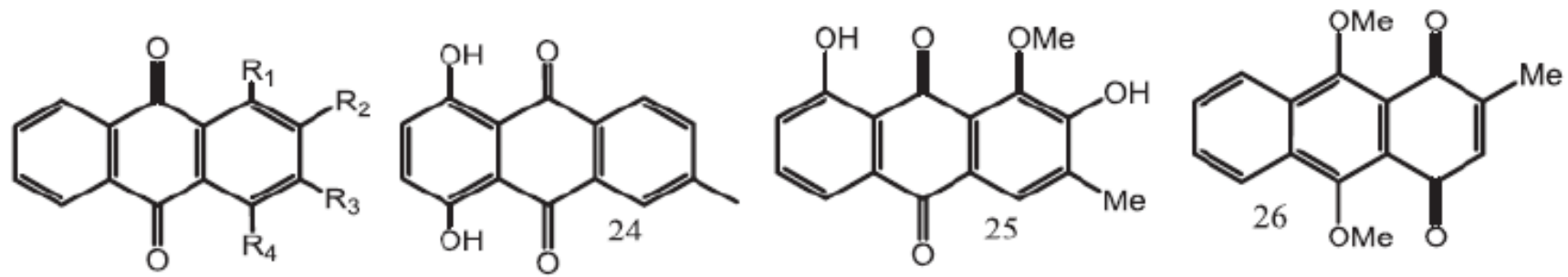

$12 \mathrm{R}_{1}=\mathrm{R}_{3}=\mathrm{R}_{4}=\mathrm{H}, \mathrm{R}_{2}=\mathrm{CH}_{3}$

$13 \mathrm{R}_{1}=\mathrm{R}_{3}=\mathrm{R}_{4}=\mathrm{H}, \mathrm{R}_{2}=\mathrm{CH}_{2} \mathrm{OH}$

$14 \mathrm{R}_{1}=\mathrm{R}_{3}=\mathrm{R}_{4}=\mathrm{H}, \mathrm{R}_{2}=\mathrm{CH}_{2} \mathrm{OAc}$

$15 \mathrm{R}_{1}=\mathrm{R}_{3}=\mathrm{R}_{4}=\mathrm{H}, \mathrm{R}_{2}=\mathrm{CHO}$

$16 \mathrm{R}_{1}=\mathrm{R}_{3}=\mathrm{R}_{4}=\mathrm{H}, \mathrm{R}_{2}=\mathrm{COOH}$

$17 \mathrm{R}_{1}=\mathrm{R}_{4}=\mathrm{H}, \mathrm{R}_{2}=\mathrm{CH}_{3}, \mathrm{R}_{3}=\mathrm{OH}$

$18 \mathrm{R}_{1}=\mathrm{OH}, \mathrm{R}_{2}=\mathrm{R}_{4}=\mathrm{H}, \mathrm{R}_{3}=\mathrm{CH}_{3}$

$19 \mathrm{R}_{1}=\mathrm{R}_{3}=\mathrm{OH}, \mathrm{R}_{2}=\mathrm{CH}_{3}, \mathrm{R}_{4}=\mathrm{H}$<smiles>[R]c1cc2c(c([R])c1[R])[C@@H](O)c1cccc([R4])c1C(=O)c1cccc([R])c1-2</smiles>

$27 \mathrm{R}_{1}=\mathrm{H}, \mathrm{R}_{2}=\mathrm{CH}_{3}, \mathrm{R}_{3}=\mathrm{H}, \mathrm{R}_{4}=\mathrm{OH}$

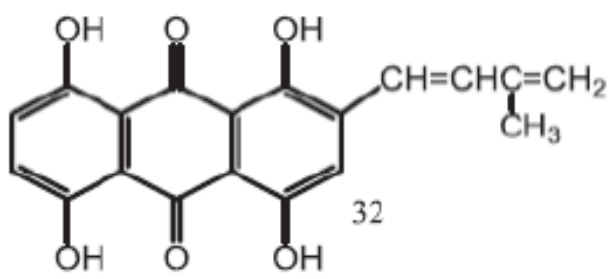

$20 \mathrm{R}_{1}=\mathrm{R}_{3}=\mathrm{OH}, \mathrm{R}_{2}=\mathrm{COOH}, \mathrm{R}_{4}=\mathrm{H} 29 \mathrm{R}_{1}=\mathrm{OH}, \mathrm{R}_{2}=\mathrm{CH}_{3}, \mathrm{R}_{3}=\mathrm{H}, \mathrm{R}_{4}=\mathrm{OH}$

$21 \mathrm{R}_{1}-\mathrm{R}_{4}-\mathrm{OH}, \mathrm{R}_{2}-\mathrm{Me}, \mathrm{R}_{3}-\mathrm{H}$,

$22 \mathrm{R}_{1}=\mathrm{R}_{4}=\mathrm{OH}, \mathrm{R}_{2}=\mathrm{R}_{3}-\mathrm{H}$

$23 \mathrm{R}_{1}=\mathrm{OH}, \mathrm{R}_{2}=\mathrm{CH}_{3}, \mathrm{R}_{3}=\mathrm{R}_{4}=\mathrm{H}$

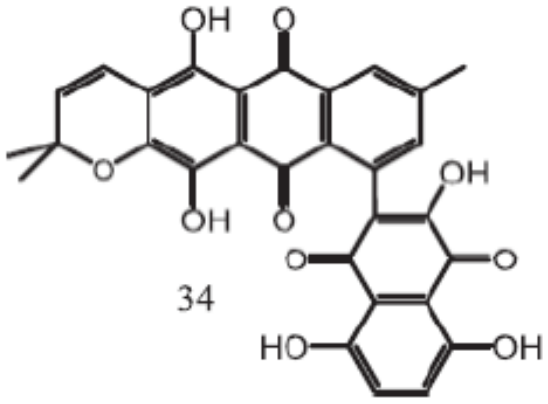

$30 \mathrm{R}_{1}=\mathrm{OCH}_{3}, \mathrm{R}_{2}=\mathrm{OH}, \mathrm{R}_{3}=\mathrm{Me}, \mathrm{R}_{4}=\mathrm{OH}$

$31 \mathrm{R}_{1}=\mathrm{R}_{2}-\mathrm{H}, \mathrm{R}_{3}=\mathrm{CH}_{3}, \mathrm{R}_{4}-\mathrm{OH}$
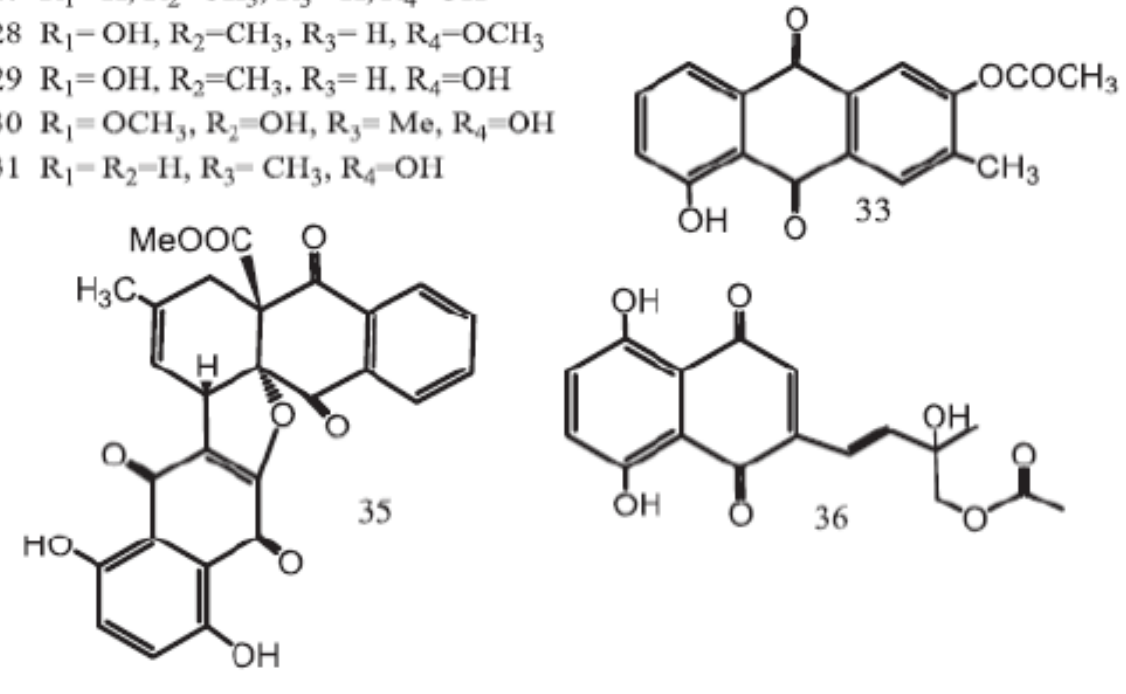

Figure 1

Chemical structures of anthraquinones. 


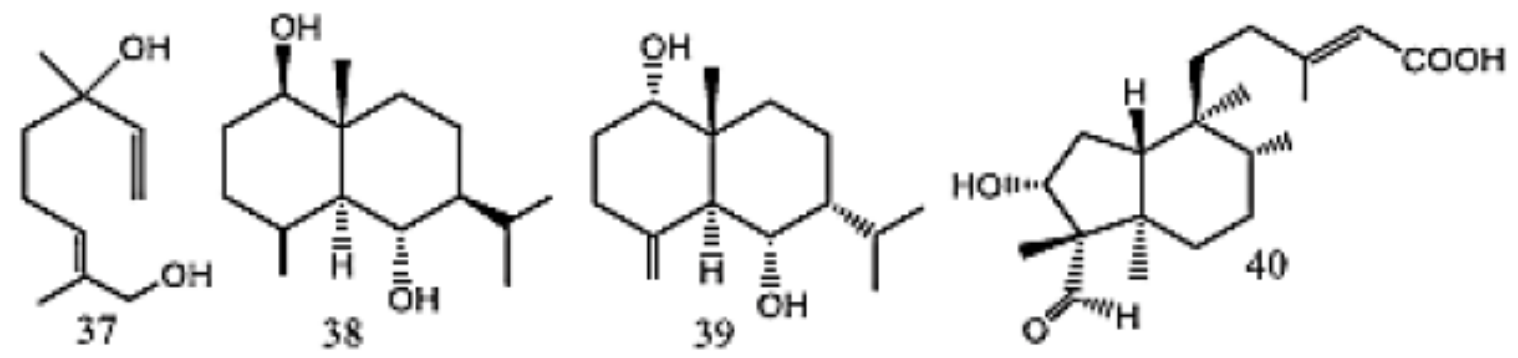<smiles>C/C(=C\CO)CCCC(C)CCCC(C)CCCC(C)C</smiles>

41

(2)

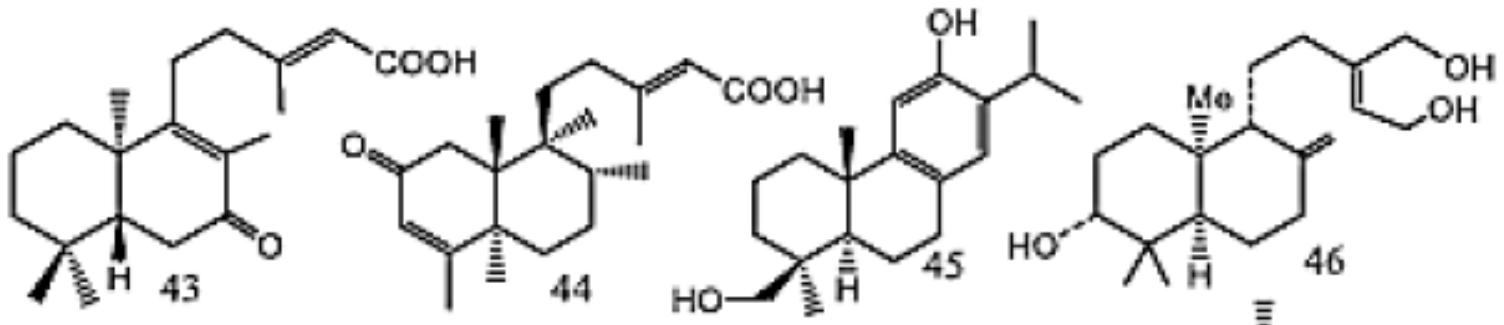

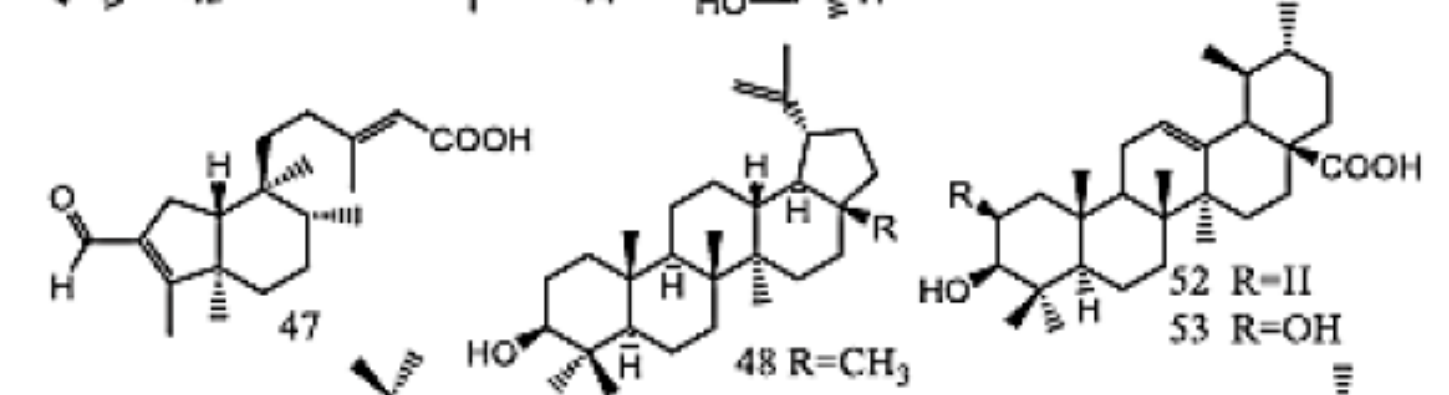

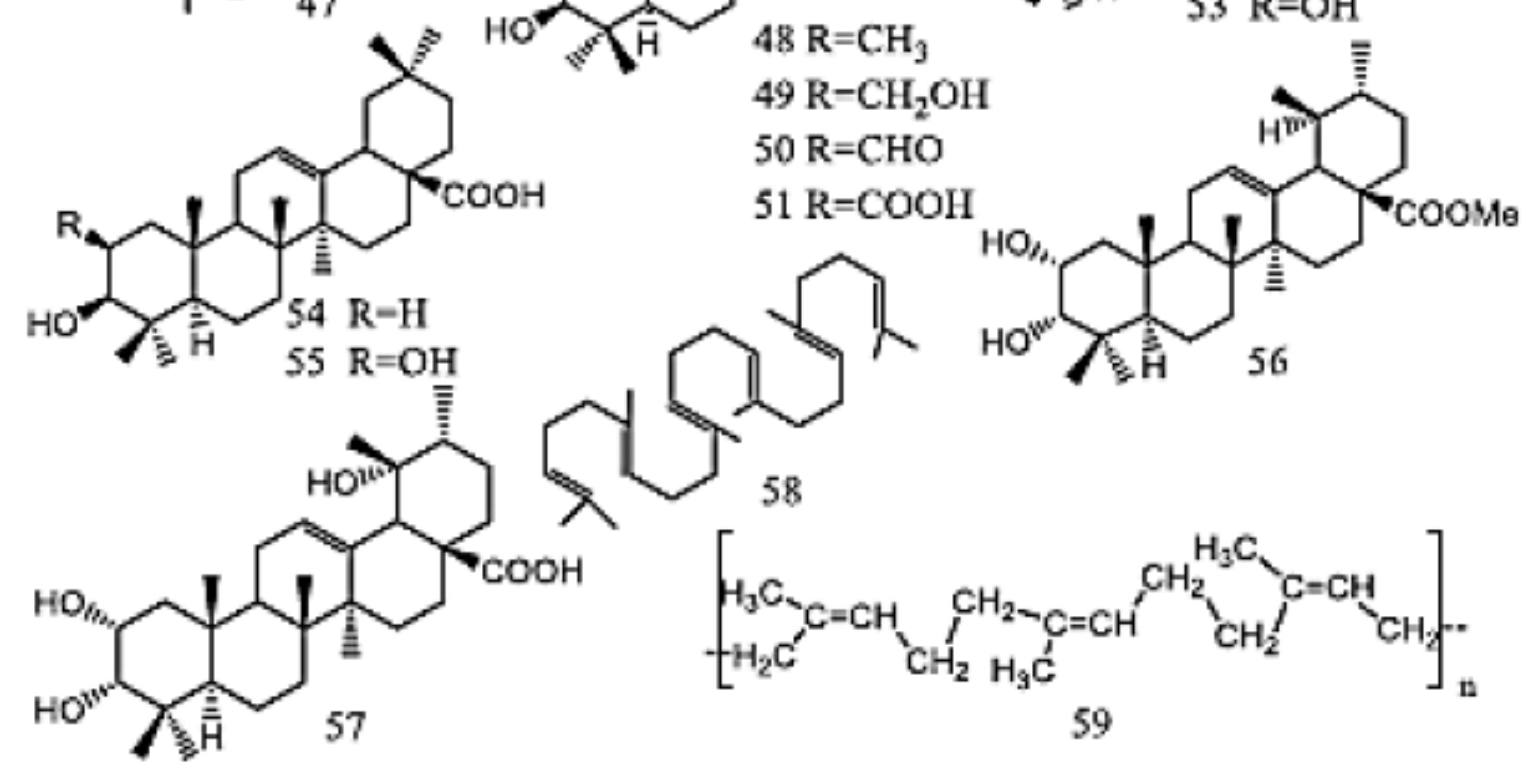

Figure 2

Chemical structures of terpenoids. 


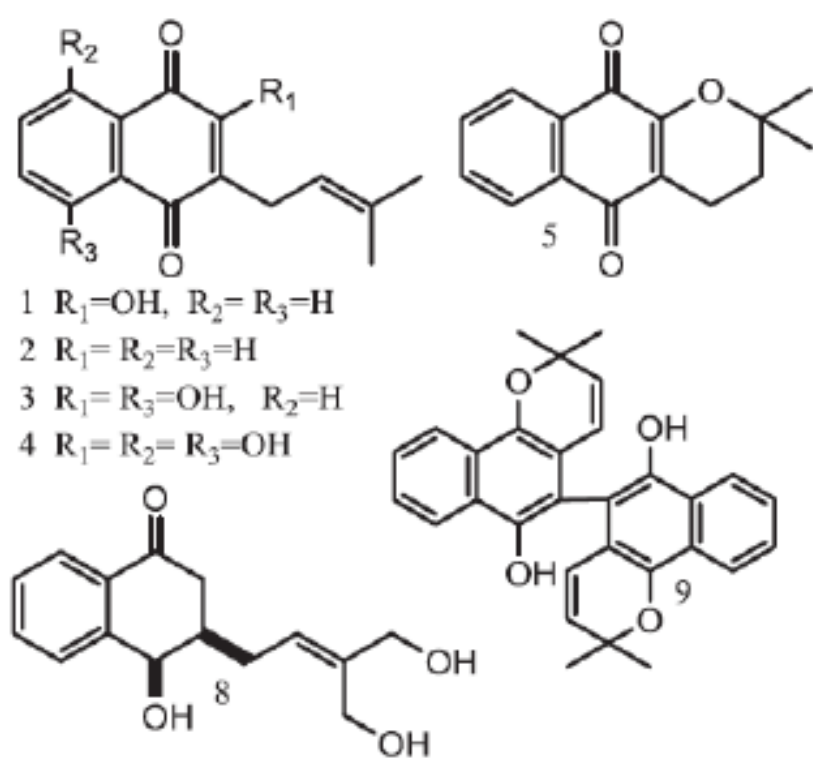<smiles>CC1(C)CCC2=C(O1)c1ccccc1C(=O)C2=O</smiles><smiles>CC1(C)C=CC2=C(O1)C(=O)c1ccccc1C2=O</smiles>

Figure 3

Chemical structures of naphthoquinones<smiles>O=C(O)c1cc(O)c(O)c(O)c1</smiles><smiles>O=C1Oc2c(O)c(O)cc3c2C2C1=C(O)C(O)=CC2C(=O)O3</smiles><smiles>COc1cc(C(C)=O)ccc1O</smiles><smiles>COc1cc(/C=C/C=O)ccc1O</smiles><smiles>COc1cc(C(=O)CCO)cc(OC)c1O</smiles><smiles>COc1cc(C(=O)C(CO)c2ccc(O)c(OC)c2)ccc1O</smiles>

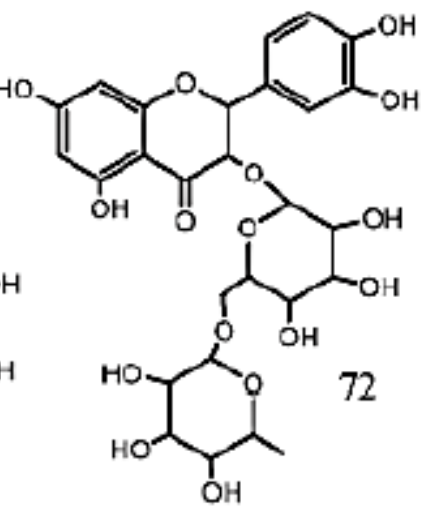

Figure 4

Chemical structures of phenolic compounds (66-71) and flavonoids (72-73). 


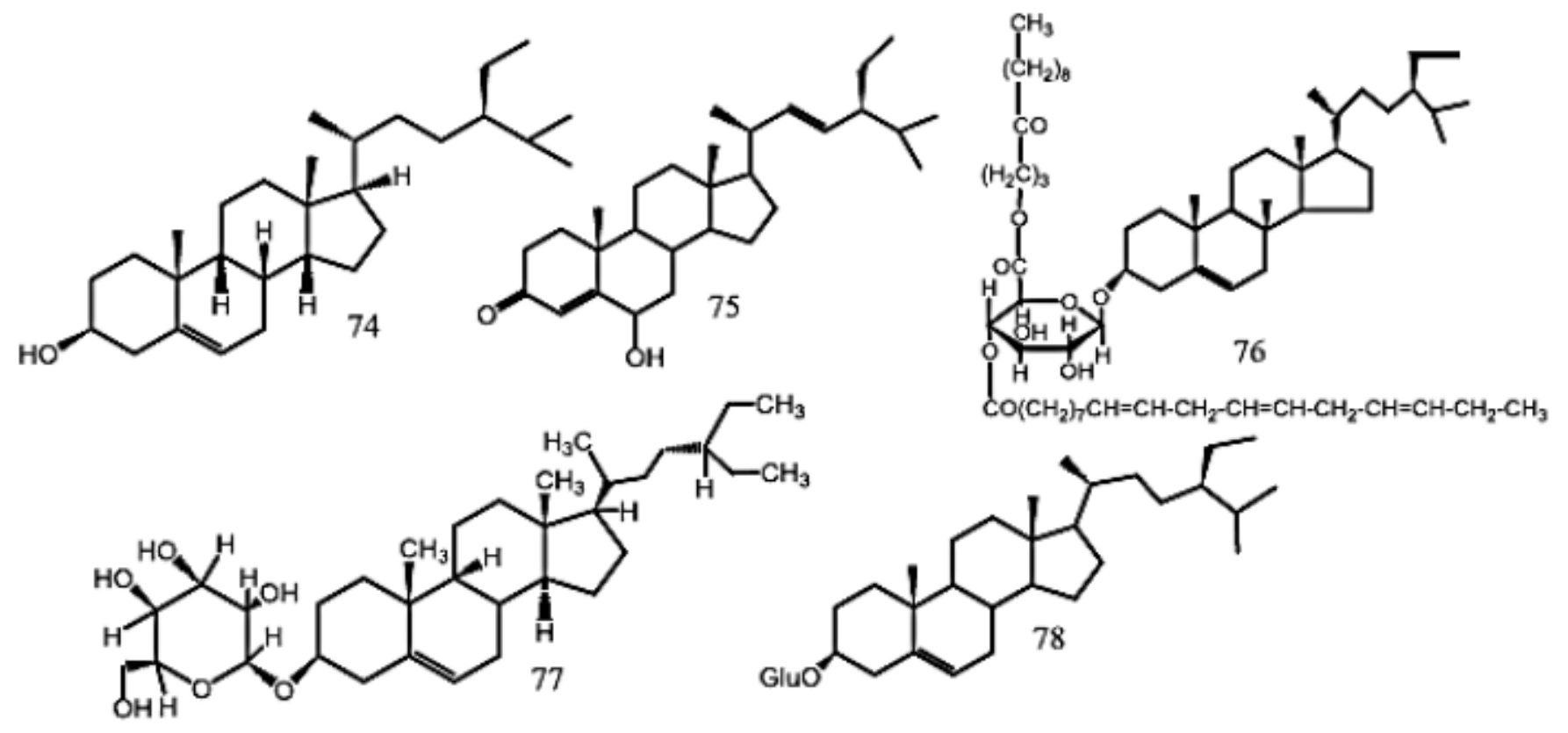

Figure 5

Chemical structures of streroids/saponins.

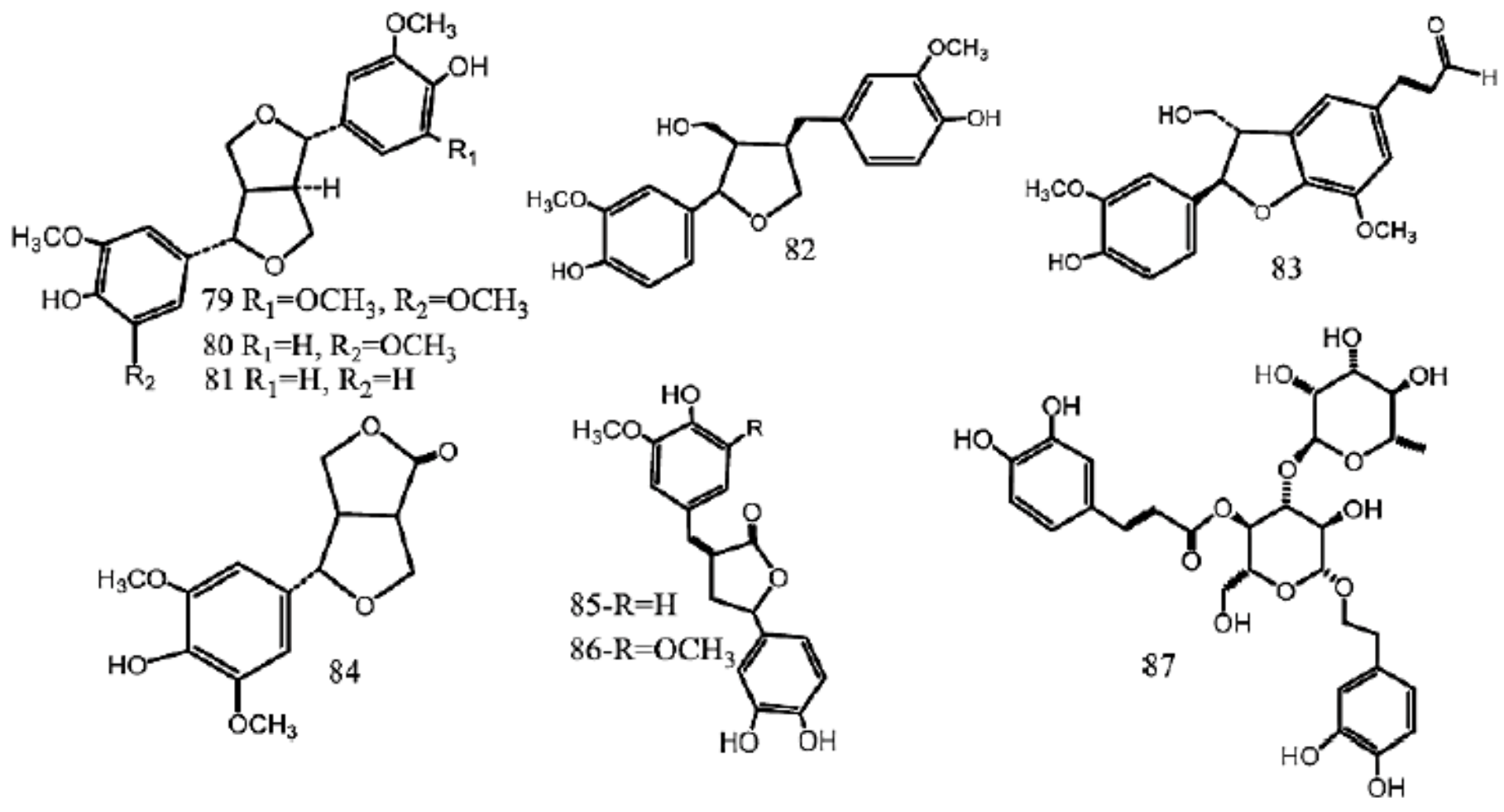

Figure 6 
Chemical structures of phenylpropanoids (79-86) \& phenylehtanoid glycoside (87).<smiles>CC(=O)/C=C/[C@]1(C)C[C@@H](O)C[C@]2(C)O[C@]2(C)C1</smiles><smiles>CC1=C(CCC(C)O)C(C)(C)C[C@H](O)C1</smiles>

63<smiles>CC1=C(CC[C@H](C)O)C(C)(C)CCC1=O</smiles>

62<smiles>CC(=O)CCC1=C(C)C[C@@H](O)CC1(C)C</smiles>

65

Figure 7

Chemical structures of apocarotenoids.
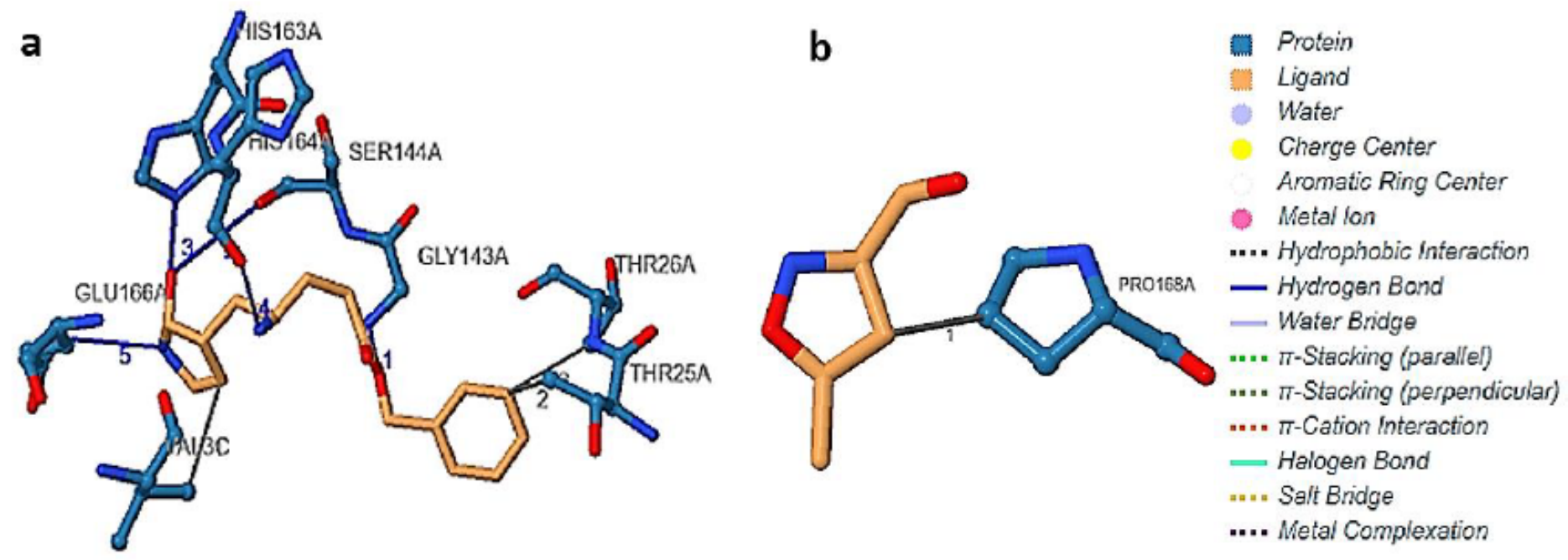

Figure 8

Represents the active sites (Ligand binding) in 6LU7. 6LU7 has 2 interacting chains. (a) Small molecule02J (5methylisoxazole-3-carboxylic acid) interacting chain A (b) PJE (composite ligand) PJE- C-5 interacting chains $A, C$. 

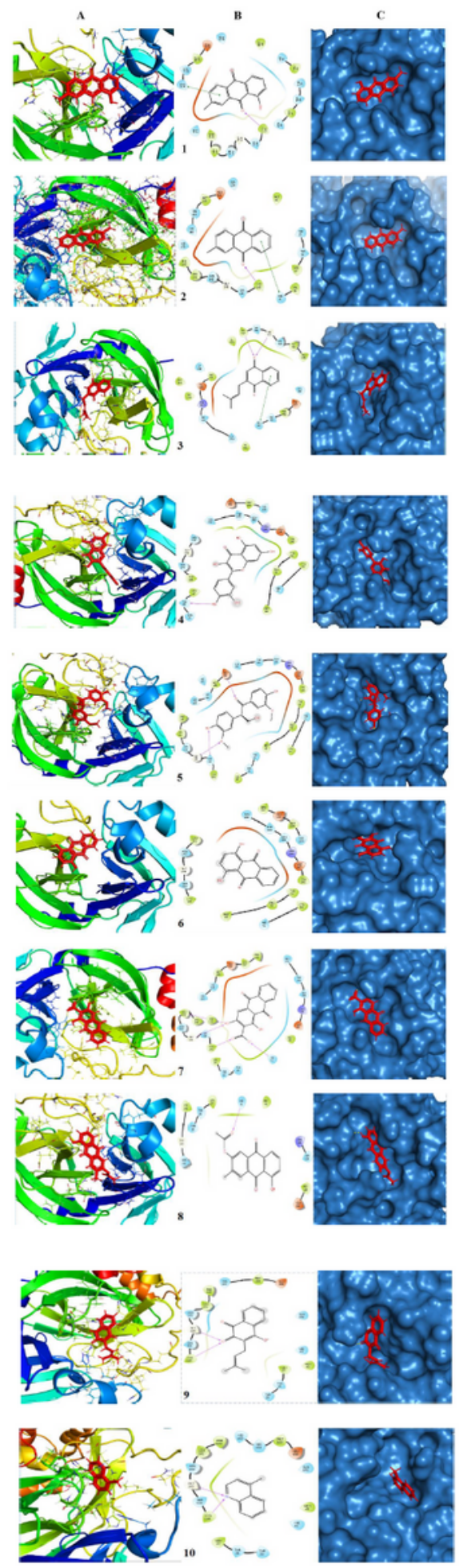

Figure 9

Molecular docking analysis between 6LU7 top 10 selected compounds from table 2 . 


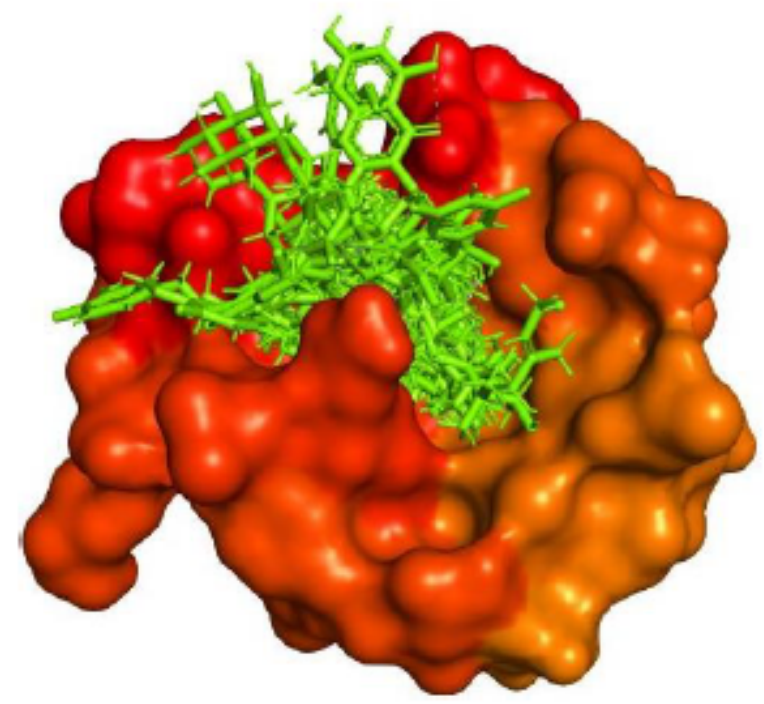

Figure 10

Interaction of selected compounds at the active site of COVID-19 Mpro

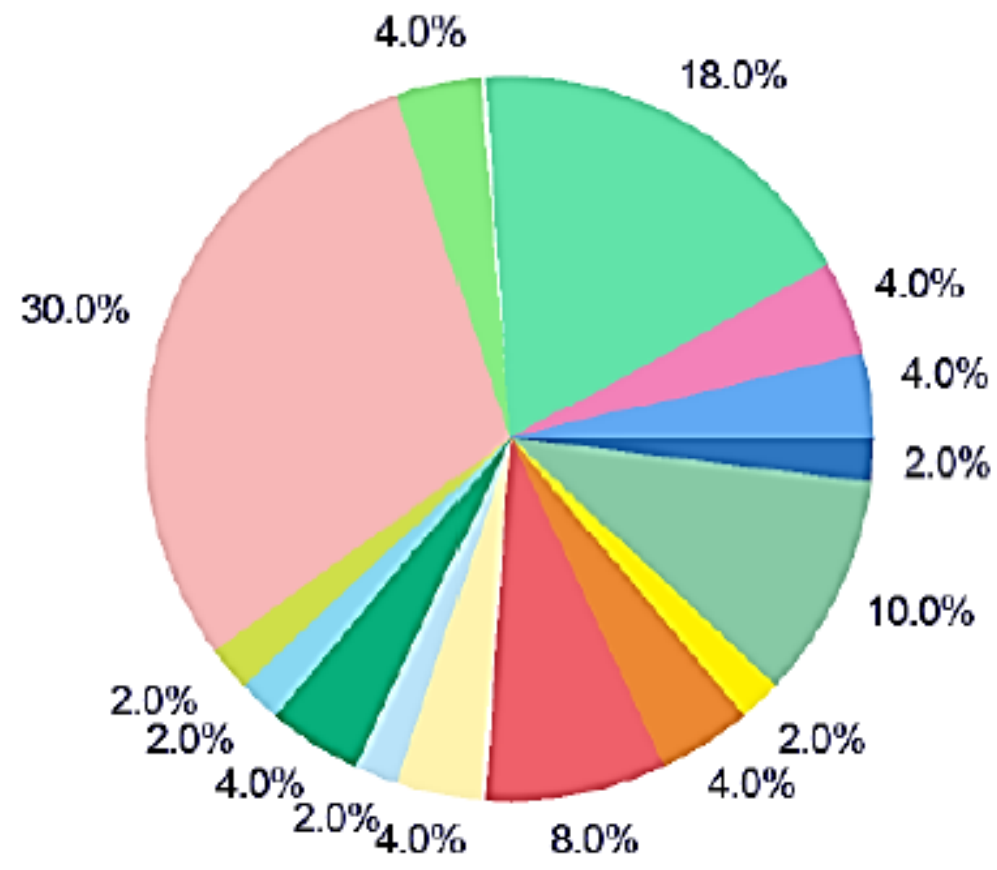

$\begin{array}{lll}\square \text { Protease } & \square \text { Nuclear receptor } & \square \text { Knase } \\ \square \text { Phosphatase } & \square \text { Enzyme } & \square \text { Other cytosolic protein } \\ \square \text { Cytochrome P450 } & \square \text { Oxidoreductase } & \square \text { Other ion channel } \\ \square \text { Unclassified protein } & \square \text { Family AG protein-coupled receptor } & \square \text { Lyase } \\ \square \text { Voltag̣egated ion channel } & \square \text { Lig̣and-g̣ated ion channel } & \square \text { Sacretedprotein }\end{array}$

Figure 11

Predicted target group for Barleriaquinone-I 


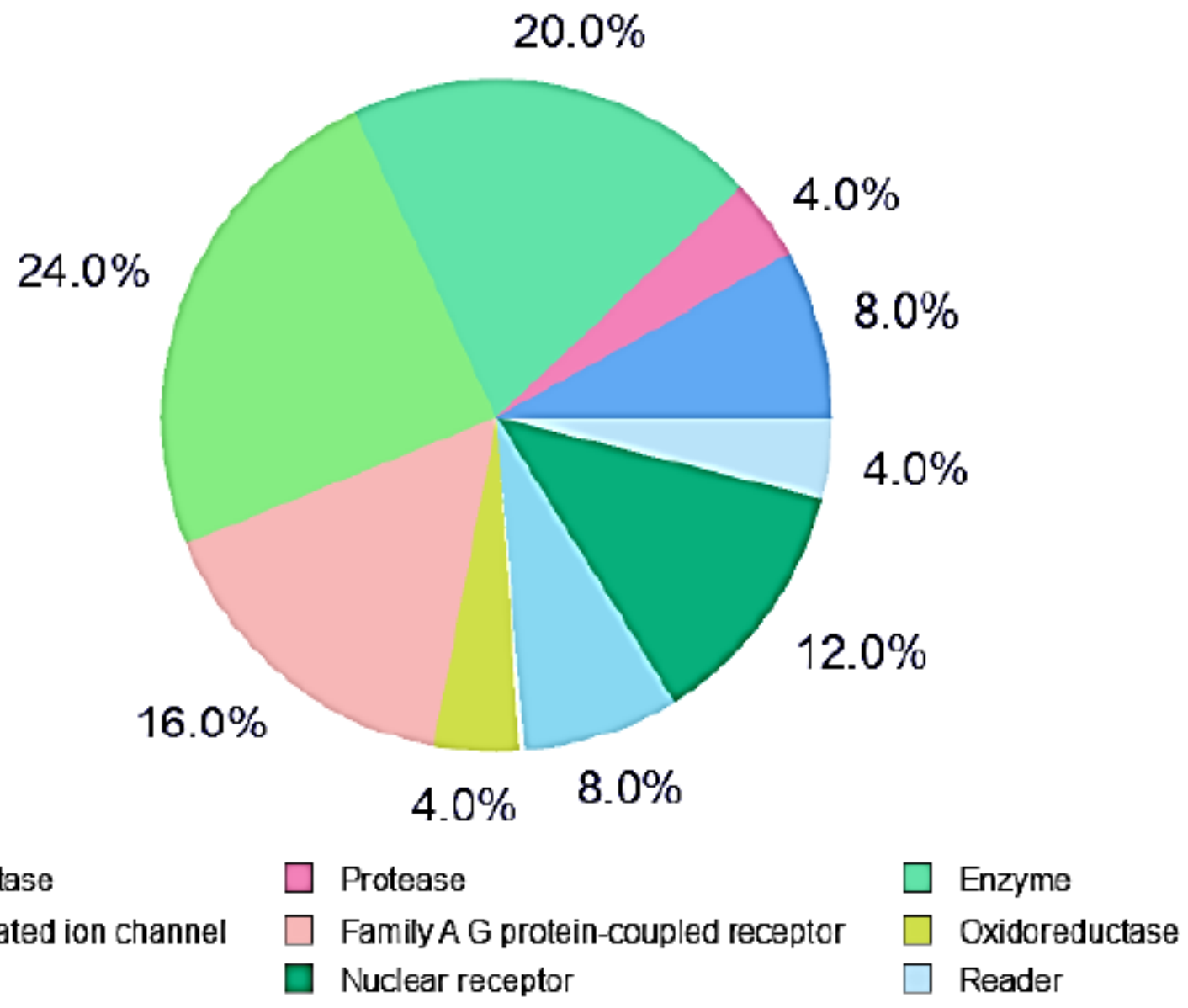

Figure 12

Predicted target group for Tectoquinone 


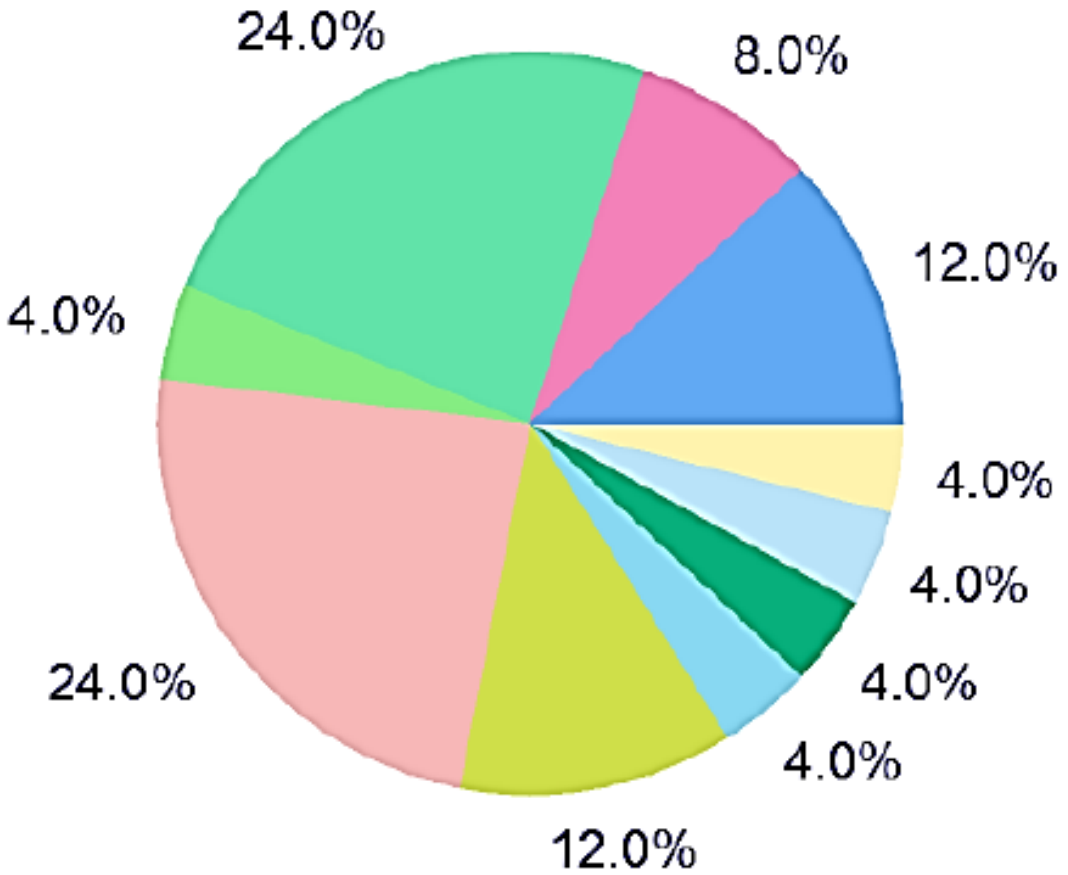

$\square$ Oxidoreductase

$\square$ Enzyme

Phosphatase

$\square$ Ligand-gated ion channel

Family A G protein-coupled receptor

Nuclear receptor

$\square$ Family C G protein-coupled receptor

$\square$ Electrochemical transporter

Voltage-gated ion channel

Figure 13

Predicted target group for Deoxylapachol

\section{Supplementary Files}

This is a list of supplementary files associated with this preprint. Click to download.

- Table3.docx 